NBSIR 81-2309

\title{
An Evaluation of Assigning Credit/Debit to the Energy Factor of Clothes Washers Based on Water Extraction Performance
}

\author{
U.S. DEPARTMENT OF COMMERCE \\ National Bureau of Standards \\ National Engineering Laboratory \\ Center for Consumer Product Technology \\ Washington, D.C. 20234
}

August 1981

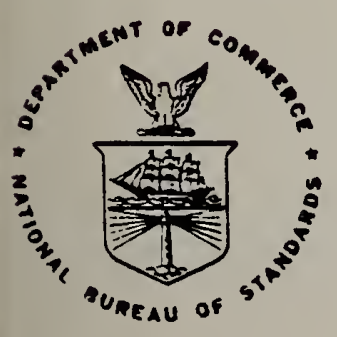

U.S. DEPARTMENT OF COMMERCE

NATIONAL BUREAU OF STANDARDS 



\title{
AN EVALUATION OF ASSIGNING CREDIT/DEBIT TO THE ENERGY FACTOR OF CLOTHES WASHERS BASED ON WATER EXTRACTION PERFORMANCE
}

C. Denver Lovett

\begin{abstract}
U.S. DEPARTMENT OF COMMERCE
National Bureau of Standards

National Engineering Laboratory

Center for Consumer Product Technology

Washington, D.C. 20234
\end{abstract}

August 1981

U.S. DEPARTMENT OF COMMERCE, Malcolm Baldrige, Secretary NATIONAL BUREAU OF STANDARDS, Ernest Ambler, Director 

I. Introduction . ....................

A. Objective

B. Background

C. Energy Savings

D. National Significance of Reducing Moisture Retention

II. Parameters Affecting Moisture Retention . . . . . . . : 3

A. Effects of Spin Time . . . . . . . . . . . . 3

B. The Effect of Spin Speed and Load Type . . . . . . . . 3

C. Cold Water Rinse . . . . . . . . . . . . . 4

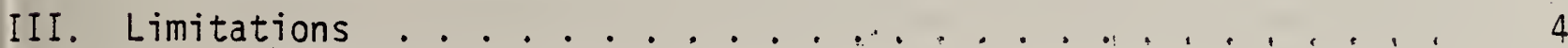

A. Vibrations .................... . 5

B. Wrinkle Performance . . . . . . . . . . . 5

C. Cost Anatysis ................. 6

IV. Energy Factor Credit/Debit Analysis. . . . . . . , . . 7

A. Need for Credit/Debit . . . . . . . . . . . . 7

B. First Approach to Credit/Debit . . . . . . . . . . . . 7

C. Second Approach to Credit/Debit . . . . . 8

D. Energy Factor as Affected by Credit/Debit . . . . . . . , 8

V. Conclusions ................... 10

References ..................... 11 
List of Figures

Page

Figure 1 A Diagrammatic Illustration of Moisture Transfer Between

Clothes Washer and Clothes Dryer............ 12

Figure 2 Incremental Dryer Efficiency Versus Moisture Retention . . . . 13

Figure 3 Water Retention Versus Test Load Weight for Clothes

Washers A, E, H ............... 14

Figure 4 Clothes Dryer Energy Consumption for Drying Test Loads Spun In

Two Clothes Washers ............. 15

Figure 5 Moisture Retention Versus Spin-Time for Three Clothes Washers. . 16

Figure 6 Clothes Washer H Moisutre Retention Versus Tub Spin Speed . . . 17

Figure 7 Clothes Dryer Energy Consumption Versus Initial Moisture

Retention ............... 18

Figure 8 Change in Moisture Retention Rate Versus Spin Speed . . . . 19

Figure 9 Evaluation of Wrinkle Hypothesis by Six Judges . . . . . . . 20

Figure $10^{\circ}$ Credits/Debits to Influence The Energy Efficiency Factors of Clothes Washers ................ 21

Figure 17 Credits and Debits to Influence The Energy Efficiency Factors of Clothes Washers ............... 22

Figure 12 Clothes Washer Energy Factor, As Effected by Credits and Debits for Reduction in Moisture Retention

\section{List of Tables}

TABLE 1. Clothes Dryer Incremental Energy Efficiency and Amount of Water Removed During Each 5 Minute Interval . . . . . . . 24

TABLE 2. Water Retention for Various Clothes Washers with 6 Pound Test Load . . . . . . . . . . . . . . . . . . 25

TABLE 3. Potential Dryer Energy Savings for Various Moisture Retentions in a Seven Pound Test Load . . . . . . . . . . . . 26

TABLE 4. Potential Dollar Energy Savings for Various Holding Periods • . 27

TABLE 5. Machine Capacity and Energy Consumption Data. . . . . . . 28

TABLE 6. Debit/Credit from Figure $11 \ldots \ldots . \ldots . . . . . . . . .29$ 
TABLE 7. Energy Factor and Energy Factor Change as a Function of Water Retention for Two Washers, Using Proposed Credit/Debit Plan. . . . 30

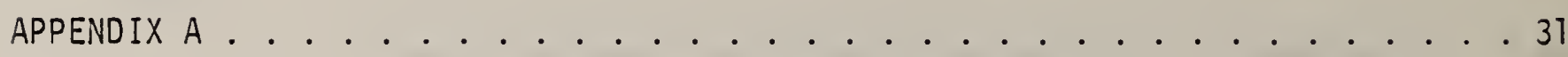


Abstract

To reduce the moisture retention of a clothes load from $65 \%$ to $40 \%$, a clothes dryer uses about 200 times more energy than a clothes washer. Therefore, improving the clothes washer's water extraction performance can significantly reduce energy-use of a dryer. For example, a clothes dryer uses about $40 \%$ less energy, when the clothes washer extracts $38 \%$ more water from the clothes load. Based on clothes washer extraction performance, NBS has developed, for the Department of Energy (DOE), a procedure for assigning credit/debit to the energy factor of a clothes washer. The purpose of this procedure is to provide an incentative for clothes washer manufacturers to improve the water extraction performance of washers. Using this procedure, the energy factors for two clothes washers improves by $44 \%$ and $28 \%$ respectively. This energy factor improvement corresponds to improved water extraction which reduces the moisture retention of the clothes load from $65 \%$ to $40 \%$. One case study shows that dryer energy savings, resulting from reduced moisture content, justifies $1 \$ 50$ incremental cost for improved water extraction performance for clothes washers. 



\section{Introruction}

\section{A. Ohiective}

An integrated approach to appliance energy consumption involves determining what effect the energy consumption and the performance attrikutes of one appliance has on the energy consurption and performance of another appliance. of particular interest in this case is the performance of a clothes washer during water extraction (i.e., spin cycle) and the effect on the clothes iryer enerpy consumption. The more water that remains in the clothes load after the spin cycle, the more enerpy that mist he expender in the irying process. The matior emphasis of this study is to devise a plan for assignine crenits/iehits to the clothes washer for the enersy effect on the clothes iryer. This study wi.l. examine the eneroy cost traie-nffs of extractine practical amounts of water during the spin cycle versus remoring excess water by means of thermal energy in the clothes iryer. In adiition, other performance related attrihutes that may he adversely affected by increased water extraction using the soin methor are identifier.

\section{3ackorround}

The cost for water extraction hy mechanical enerry in the clothes washer is small in comparision with the cost, of supplying therma? energy to the clothes load during the drying cycle in a dryer. Figure 1 shows the moisture transfer between a washer, a dryer, and the environment, and the corresponding amounts of energy required for extracting water in the clothes washer and the clothes iryer. For example, an average value for the machine electrical enerfy during a full wash cycle including the spin cycle is about $0.25 \mathrm{kilcwatt-hour.} \mathrm{If} \mathrm{one}$ assumes that $20 \%$ of the total machine's electrical enerey is user during the spin cycle, this would amount to only 50 watt-hours.

Iimiter test iata indicates that the amount of water remover from a standard 7 Ih test Ioad $[1]^{*}$ during the spin cycle from the "तrip wet" conditions to the "spin iry" condition is 9.5 pounds of water. Therefore, the water extraction during the spin cycle is 190 Ins of water $/ \mathrm{kWh} l=9.5 \mathrm{Ib} / .050$ $\mathrm{k}$ Wh). This value compares with an average water removal hy clothes iryers of 2.07 ?. hs of water/kWh. This ratio is the average of the incremental dryer ratio corresponding to moisture retention values between $70 \%$ and $40 \%$ ! see Figure 2 and Tahle 1). Therefore, the ratio of water remova? during the clnthes washer soin cycle to clothes dryer thermal cycle is about 90. Although within certain ranges of moisture removals, it is 90 times more efficient to extract water during the clothes washer spin cycle than during clothes iryer thermal cycle, there are practical limitations to the amount of water that can he extracter hy means of mechanical energy.

The amount of water removed from a test loa varies from clothes washer to clothes washer. The test data shown in Tahle 2 and plotter in Fioure 3

* Numbers in hrackets refer to the references at the ent of this report. 
indicates that the clothes load moisture retention for different machines varies from $74 \%$ to $50 \%$ depending on the temperature of rinse and the weight of clothes Ioar. For a 7 in test load this variation in moisture retention amounts to 1.05 pounis of water $(=0.70 \times 7$ lhs $-0.55 \times 7$ Ihs $)$.

If a 7 Ih test, load spun in a clothes washer resulted in a $70 \%$ water retention rather than a 55\% moisture retention, the clothes iryer would have to expend an additional $0.5 \mathrm{kWh}(=1.05 \mathrm{lbs} / 2.07 \mathrm{lh} / \mathrm{k} / \mathrm{h})$. Therefore, 3. clothes washer resulting in 55\% moisture retention for a 7 Ib test loar would contrihute simificantly in reducing eneroy required to iry this loan. These results are presented to indicate the significant variation in the amcunt of energy reauired to dry a load when various clothes washers are user to prepare a load for the same clothes iryer.

\section{Enerey Sarings}

To compare the effect of clothes washer spin performance on the eneroy consumption of clothes dryers, it is logica? to select 70 m moisture retention as the baseline case since starting moisture retention for the 7 in test load specified in the clothes dryer test procedure is $70+3.5 \%$. Clothes washers which spin the loar to below 70\%, moisture retentinn may he considere to achieve energy savines for the clothes iryer. Conversely, clothes washers which spin the load to a moisture retention value ahove $70 \%$ may he consideren to he wasting enerpy in the clothes dryer. Table 3 shows the relationship between moisture retention and the corresponding computed levels of eneroy savings for the clothes dryer. These data indicate, for example, that for a $40 \%$ moisture retention, the possible energy sarines in a clothes iryer is $1.0 \mathrm{kWh}$.

\section{National Significance of Reducing Moisture Retention}

To estahlish a hase case, assume that all clothes loads have a starting moisture retention of $65 \%$ (weighted average). If the extraction performance of clothes washers can he improved such that the weighter ave rage moisture retention of all clothes loads are $40 \%$. the starting moisture weight of the clothes load would he reduced hy 1.75 Ihs (for a 7 in test $10 a$ ). A reduction in wet load weight hy 1.75 Ihs corresponds to an energy saving for the clothes iryer of ahout $0.85 \mathrm{kWh}$. On a per cycle basis, this $0.85 \mathrm{kWh}$ savines represents ahout a 38\%, savines. It should be noted that this estimater eneroy savinos is hased on an averape iryer efficiency of 2.07 lhs of water per kilowatt-hour.

The rariation in clothes iryer efficiency over certain ranoes of moisture retention is shown in Figure 2. Fipure 4 shows the test iata relating enerox consumption and efficiency of dryer A when the test 1oad is spun to $70 \%$ moistire retention by washer I and compared to $40 \%$ moisture retention when spun in washer $G$. On an anmua] basis, the $0.85 \mathrm{kWh}$ savinos per cycle corresponds to an enerfy savings of $354 \mathrm{kWh}$ or a dollar savings of about $\$ 20$ per year haser on 8 cycles per week and an energy cost of $5.64 \mathrm{k} / \mathrm{kWh}$. From a national riewpoint, the sayings of $354 \mathrm{kWh}$ per dryer would represent, a national energy savinf of $1.3 .9 \mathrm{y}$ $10^{-9} \mathrm{kWh}$ per year (354 kWh/unit $\times 39 \times 10^{6}$ units) or ahout, 8 million harrels of oil. equivalent per jear. 
The mechanical. enerfy required to chtain hioher water extraction iurino the spin cycle is negligible (ahout ld in comparison with the potentia? therma.l energy savines in the clothes dryer.

\section{Parameters Affecting Moisture Retention}

The clothes load water retention is affected hy:

1. the characteristic of the particular clothes loar,

2. the machine operating characteristics, and

3. the rinse water temperature.

The primary characteristics. that affect clothes load water retainino ahility are the weight and composition of the fahric (cotton, synthetic etc.'. For example, a load composed of all cotton fahric tenis to retain about twice as much water as a blend of $50 \%$ cotton and $50 \%$ polyester. In ceneral, the nercent water retention cecreases with increasing 7 oar weight, Figure 3.

The machine parameters which afferts moisture retention of the clothes loa, are spin speed, spin time, and hasket diameter. Only spin speed and spin time are practical desion options for increasing moisture extractinn. Increasinf spin speet offers the oreatest potential for improving water extraction. Increasing spin time is the easiest desion cotion to implement, however, it offers only a morest potential for improring extraction efficiency.

The temperature of the rinse water that preceers the sinat extraction rvcle has a modest (ahout $5 \%$ ) effect on the water-retention of the clothes loar. Tests have shown the temperature of the rinse water affects the amount of water extracted. See Tahle II. One possihility to explain this is that cold water rinse causes a more viscous water to remain in the clothes loan. since cold water has a hipher surface tension, hioher centrifupal forces are requires. To quantify these effects the followino test iata are presented:

\section{A. Effects of Spin Time}

Test results (See Fipure 5) shows that when the snin time of four minutes is increased hy a factor of three. the moisture retention of a staniart test load is reducen by five to ten percentage points. Fipure 5 shows the variation in moisture retention of three clothes washers, A, I, and G. The moisture retention of the clothes ?oad soun in machine $G$ approach $40 \%$ after ahout, 12 minutes of spin.

\section{B. The Effent of Spin Speed and Loar Type}

Moisture extraction tests were nerformed hy using a standard size householi clothes washer which was modified to accept a variahle speed drive motor. This clothes washer had a six minute spin cycle, therefore al. spin test. were conducted for six mimutes. Two types of test loars were selected to examine the effects of loar composition. One lcar was a seren-pound staniard 
test load which consisted of a blend fahric of $50 \%$ cotton $/ 50 \%$ polyester and the other load was a seven pound load which consisted of $100 \%$ cotton fabric.

Figure 6 shows the variation in the mosture retention for each test load as the spin speed was increased from $400 \mathrm{rpm}$ to $9.00 \mathrm{rmm}$. Each 7 oar was suhsequentiy dried in the same dryer to ahout 30\% moisture level. Fionre 7 shows the variation in energy use to dry each load for various va?ues of initial moisture retention which corresponds to spin speeds hetween $400 \mathrm{rrom}$ and $900 \mathrm{rpm}$. Fioure 7 indicates that for a standard test road the energy used hy the iryer was reduced from $2.42 \mathrm{kWh}$ to $1.28 \mathrm{kWh}$ when the initial moisture retention was reduce from $77 \%$ respectively to $40 \%$. This is a $47 \%$ reduction in the eneroy used hy the dryer.

Fioure 6 shows that for the 100 . cotton test loar, the 400 rom spin speed resulted in a $93 \%$ moisture retention and the 900 rom spin speer resur.ten in a. 63\% moisture retention. These corresponding retention va? ues can he ccmparen with $77 \%$ and $40 \%$ for the standard test, 1 oar (with a $50 \%$ cotton/50\% polyesters). Fizure 7 , shows that the clothes dryer used $2.96 \mathrm{kWh}$ to iry a l.00\% cotton load from a $93 \%$ moisture retention to a $3 \%$ final moisture retention. These results represent an energy saring of ahout $28^{\%}$ if the initial roisture retention of a $100 \%$ cotton load is $63 \%$ instead of $93 \%$.

Fingre 8 is the derivative of the roisture retention versus snin speet variation shown in Fi,ure 6 . These "ata show that the water moisture retention ver change in rpm was ahout 2.5 times greater at $425 \mathrm{rpm}$ than at $875 \mathrm{rmm}$. At, $425 \mathrm{rpm}$ the moisture retention oer unit change in rom was 0.12 nercent per rpm. Whereas at $875 \mathrm{rpm}$ the moisture retention rate was 0.046 percent, per rpm. These results suegest, as might he expected, that more water is removed at hicher soin speeds and that the more that has heen removed, the more difficu?t it is to remove the remaining water.

\section{Cold Water Rinse}

The effect that col.d. water rinse has on water extraction was determinen from previous work done at NBS. These test results were presented in a milestone report titler "The Effect of Water Temperature on Washing Performance" 127. Some of these test results are presented in Mahle 2 and show that the iifference in water retention is typically ahout five percentape points hi, sher for cold water rinsing. These iata sugpest that rue to slightig hi,cher initial moisture retention, an additiona? smaly amount of eneroy is used in the dryer to remove this additional amount of water $(0.35$ ins of water for a stancard test. load) corresponding to $5 \%$ higher initial roisture retention. However the energy saving due to using cold water rinsing as compared with warm water is ahout 20 times rreater than the incremental thermal eneroy required hy the dryer to remove this adititional amount of moisture.

\section{Iimitations}

In adiition to diminishing returns in terms of the amount of water extracted for corresponding spin speeds ahore a certain ?imit, there are 
ariitional factors that will limit the spin speer to a specified value. These factors include:

1. Higher spin speeds may require more critical halancing system to avoid excessive vibration.

2. Hither spin speeds produce larger centrifueal forces which may cause more wrink] es to remain in the clothes after iryino, and

3. Higher spin speeds may result in increased cost for drive comnonent iesion changes.

\section{A. Vibrations}

During the water extraction test in which the spin speeds were varied from 400 to $900 \mathrm{mpm}$, excessive vihration occurred in this clothes washer at 900 rom. Although the vihration which occurrer at $900 \mathrm{mpm}$ was ohiectionahle, the morerate to slipht vibrations that occurred at speeds hetween $500 \mathrm{rmm}$ to $350 \mathrm{rpm}$ were acceptahle. This qualitative evaluation of machine vihration was hased on a test of the one clothes washer which was morified to accept a variahle sneer drire and was conducted on a hard concrete f?oor. Resonant vihrations for this clothes washer with a test loar are not necessari? typica? of other clothes washers and mixed clothes loads. Vihration characteristics are iependent on the iesion parameters such as hearing location, weioht iistribution, and support stiffness of the particular clothes washer.

\section{B. Wrinkle Performance}

Some concern has been expressed that increaser spin speeds wou? calse more wrinkles to remain in the clothes. Therefore, tests were condurter to determine if hioher spin speed would cause more wrinkles to remain in the test cloth after drying.

Two irentical permanent press cloth test Ioads havino a composition of $65 \%$ polyester and $35 \%$ cotton were selected. One test load was spun at $400 \mathrm{mpm}$ and the other test, loar was, spun at $900 \mathrm{rom}$. Each test load was iried sequentially in the same clothes iryer. One groun of 12 test cloths was ohtained for evaluation hy raniomly selecting six test cloths from each of the irien lcad. Six participants visually evaluated each of the twe lve test cloths to form two orouns - one heine more winkled and the other being less wrinkled.

As shown in Fioure 9, sixty percent, of the sorted test cloths confimed the hypothesis that, higher spin speens causer more wrinkles and forty percent neqated this hypothesis. Three of the test cloths receirer irentical grouping hy all six participants and these irentical orouns were congruent, with the hypothesis. Each participant expressed difficulty in sorting the twelve test cloths into two groups of one heing more wrinkle ${ }^{4}$ than the other. The conclusion from this test is that, with exception of three test c? oths, the inf?uence of hipher spin speeds on wrinkle performance was only si iontIy 
retectahle by the six participants. The effects of repeated washings and/or higher spin speeds were not investigated, nor were actual. clothes.

The clothes iryer tends to remove some of the wrinkles that are set in the clothes during hion spin speed water extraction process. Therefore, high spin speeds are expected to cause some more wrinkles to remain in the line-rien clothes as compared with clothes dried in a clothes iryer.

\section{Cost Analysis}

Hipher water extraction, if तone hy spinning, may require a ifferent irivre motor capable of spinning the hasket to approximately $800 \mathrm{rpm}$. Because of concern for wrinkle performance, some manufacturers may chose to replace current drive motor's with two speed motors. A high speed setting for efficient water extraction and a lower speed setting recommended for use when wrinkle performance is of concern. NBS does not have reliahle cost estimates for the various water extraction iesion options which manufacturers may choose to implement; however, the incremental unit costs that are economically iustifier by the energy savines achievahle in the clothes iryer can he compluted. The econoric feasibility for hipher extraction efficiency wiJl he hased on the present value of the enerpy savines for various holding perions $(3,5,10,15$ years).

\section{Two hase cases are presented:}

Case 1 is for a change in water retention from 65\% to $40 \%$ Case 1: Retention chances by $25^{\circ}$ \%
Energy sarings
$\$ 20$
Discount rate
Holding periods
$10 \%$
Uniform series present $3,10,15$ jes.
Average drying efficiency
$2.48,3.79,6.14,7.60$
2.07 ins of water/ $\mathrm{kWh}$

Case 2: is the same as Case I except moisture retention is considered to change from $65 \%$ to $50 \%$. Thus, retention changes hy $15 \%$ and the anmual energy savings is $\$ 11.60$, all other parameters remainine the same.

These data, shown in Table 4, indicate that if the increase in nurchase cost for improved extraction performance ( $65 \%$ to $40 \%$ ) is ahout $\$ 50$ the anmual energy savings in the clothes dryer will repay (at $10 \%$, discount rate) this incrementar cost of $\$ 50$ in ahout 3 years. However. in Case 2 where the extraction performance is improved to yield a $15^{\circ}$, resuction in water retention (65\% to $50 \%$ ) it will require ahout 6 years to repay the increase in purchase cost of $\$ 50$. If improver extraction performance can he achieved for ahout $\$ 75$, it will require ahout 5 years to repay this increase in purchase cost for Case I and 10 years for Case 2. It is questionable whether a payhack period as ?ono as IO years would be generally accentab?e. However, since the expenter ecnnomic 
Iife of a clothes washer is ahout 12 years, it is expected that $z 3$ to 5 year payhack period would he accentahle.

These two cases give a reasonahle indication of the economic feasihility of increased cost for drive component desion changes for a ranpe of achievahle moisture retention an a.cceptahle payhack perions.

\section{Energy Factor Credit/Dehit Analysis}

A. Need for Credit/Dehit

The intent of the National Enery Policy and Conserration Act is to result in a program desimer to require manufacturers to procuce and encoura.pe consumers to purchase more enerpy efficient appliances. Assionino crenits to c] othes washers with superior water extraction performance may provide one method for manufacturers to improve the efficiency of clothes washers in order to meet minimum energy efficiency standards. If the credit incentive provider to the manufacturer is large enough, they may develop innovative ways of increasing water extraction.

B. First Aporoach to Credit/Debit

The first approach considered for assioning creits or dehits was to utilize a contimuous linear relationship of energy sarines with respect, to the percent of moisture retention as summarized in Mahle 3. A plot of this eneroy cresit or dehit is shown in Fioure 10. The effect of any crenits or lehits is to change the energy factor by increasing or decreasing the denominator of, the enerpy factor. The energy factor specifier. in the current test procerture is defined as useful volume (basket volume) which the clothes can oncupy dividen hy the total per cycle energy consumption.

As shown in Table 2, the range of moisture retention for most current clothes washers is hetween $74 \%$ and $50 \%$. Therefore, this approach which prescrihes crenit or dehit accordine to a contimous linear relationship as shown in Fioure 10 would award credit for most existing leve's of water extraction performance without having manufacturers make any jesion changes to improve water extraction performance. If no desion changes are ma,te to enhance spin performance, the crenits assioned to the enerpy factor will nnt he indicative of any actual dryer enerpy savings due to a recuced initial moisture retention. This apnroach has the following distinct disaciantaces:

(1) crenits are awaried for existing Jevels of extraction performance,

(2) such credits would not reflect any additional enerey saver in the clothes dryer,

(3) awarding credits for existing level of moisture retention, wold? stifle manufacturers incentive to make desion changes to further improve extraction performance, and 
(4) a linear relationship does not impose a very severe pena? fy for exceeding the hase moisture content $(70 \%)$.

\section{Second Approach to Credit/Dehit}

To overcome the disadvantapes of the first approach discusser ahove, it is proposed that the moisture retention be dividen into three ranges. The moisture values selected for diriding the spectrum into 3 ranoes are $50 \%$ and $70 \%$ moisture retention.

1. No credit nor dehit is assioner within the range of 50 of to $70^{\text {m }}$ moisture retention.

2. Creit is increased Iinearly with reruction in moisture retention kelow 50 h.

3. A constant dehit is assioned for moisture retention values that exceed $70 \%$.

The three, ranges for assigning credit and dehit are shown in Ficure 11.

A review of available moisture retention data for current, clothes washers show that a few compact clothes washers have moisture retention slightly helow $50 \%$ which will qualify for a credit. However, some standard c7othes washers have moisture retention just, above this value. Being close to this $50 \%$ value or s?ighty greater than 70\% value provides an attainahle goal which wi7l give mamufacturers the incentive to improve the water extraction efficiency of the spin cycle. The amount of eneroy credit or dehit is hased on the rifference in the pounds of water remaining in the clothes after the spin cycle and the amount of water corresponding to a $70 \%$ moisture retention (see man?e 3). Fioure 11 shows a plot of the amount of enerey cresit or iehit, corresponding to rarious moisture retention Ievels. The assumption user in determining these

credit/debit values is that each nound of water remaining in the clothes load at the end of the spin cycle requires ahout 0.48 kilh of eneroy consumption in the clothes iryer to remove the excess water. If a clothes washer spins the clothes load to 90 moisture retention, an excess of 1.4 pounds 0 - water remains in the clothes loar as compared with 70 h moisture retention. To remove this 1.4 pounis of water in the clothes iryer would require ahout $0.68 \mathrm{kWh}$. Therefore, a iehit of $0.58 \mathrm{kWh}$ would he given to clothes washers in the form of adiition to the total per cycle energy consumption, thus rerucing the clothes washer enerey factor.

\section{Energy Factor as Affected by Credit/Dehit}

The proposed creiti/dehit system will only affect the eneroy factor and not the annual operating cost. To dehit or credit the annual operating cost, hased

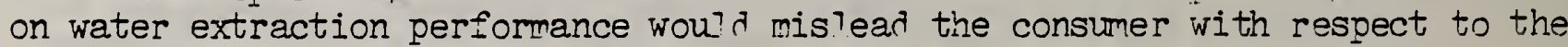
actual operating cost for a representative consumer use cycle. However, if minimum efficiency staniaris are set according to the energy factor, the proposed credit or dehit to the energy factor would provide sufficient incentive to manufacturers to improve the water extraction performance. 
To apply a creitit/debit to the energy factor, the total per cycle energy consumption would he adjusted hy the kilowatt-hour of credit/Aehit shown in Fipure 11. To illustrate, let:

$K_{1}=$ useful capacity, $\mathrm{ft}^{3}$

$I_{m}=$ total per cycle eneroy consumption, kWh

$\mathrm{R}=$ moisture retention, $\%$

From Figure 11 the energy credit, lWh:

$$
\begin{aligned}
& C=0 \text { for } 50<R<70 \\
& C=0.68+\frac{50-R}{30} \text { for } R<50 \\
& C=-0.68 \text { for } R>70 .
\end{aligned}
$$

The current energy factor, $\mathrm{FF}$, is:

$$
\mathrm{EIT}=\frac{\mathrm{K}_{1}}{\mathrm{~F}_{\mathrm{T}}} \quad \text { and }
$$

the ariusted enerog factor would he,

$$
\mathrm{EF}^{\prime}=\frac{\mathrm{K}_{1}}{\mathrm{E}_{\mathrm{ATE}}}
$$

where the aniusted total per cycle energy consumption, $\mathbb{E}_{\mathrm{ATE}}$, is:

$$
E_{\mathrm{ATE}}=E_{m}-C
$$

Therefore, the adiuster energy factor woul h he

$$
E F=\frac{K_{1}}{T-C}
$$

The following examples for clothes washers A and B are derriser to illustrate the effect that credit and dehit would hare on the enersy factor. The Jata shown in Tahle 5 for washers $A$ and $B$ and the debit and credit va?ues shown in Tahle 6 , are suhstituted into enuations 3 and 4 to obtain 7 comparison of energy factors and percentare chanee (see Tahle 7) as affected hy creitit, and dekit correspondine to various moisture retention.

Finfure 12 shows how the eneroy fact,or for washers $A$ and $B$ are affecter by various moisture retentions. An energy cresit or dehit for a given mnisture retention has a greater effect on the energy factior for washer $A$ than for washer B. For example, if the moisture retention for clothes washer A is reduced to $40 \%$, a corresponiting one $\mathrm{kWh}$ credit woul d increase the ener $\% \mathrm{w}$ factinr from 0.83 $\mathrm{ft}^{3} / \mathrm{kinh}$ to $1.19 \mathrm{ft}^{3} / \mathrm{kWh}$ which is a $44^{\text {\% }}$ improvement in the eneroy factor. 
However, if the moisture retention of clothes washer $B$ is renucer to 40 , $z$ corresponding one kih credit would increase the ener gy factor from $0.70 \mathrm{ft}^{3} / \mathrm{kWh}$ to $0.90 \mathrm{ft} / \mathrm{kWh}$ which is a $28^{\text {d }}$ improvement in the energy factor. The simificance of this example is that the higher the original. hase eneroy factor the sreater the impact of the dehit/cresit plan.

\section{Conc?usions}

For most clothes washers the water retention in a standari 7 lib test $10 a$ A range between $50 \%$ to $70 \%$ of तry test loar weint. Water extraction during a spin cycle can he imoroved ry increasing spin speed and/or spin time. However, increasing spin speed has the greatest effect on reducing moisture retention.

A credit/dehit plan has been oroposed for proviting an incentive for manufacturers to improve water extraction performance (by increasing soin speed, spin time etc.). Using this plan, a reduction in the water retention to $40 \%$ by two representative clothes washers has shown to improve the energy factor hy $44 \%$ and $28 \%$.

Anmul energy saviness of about \$20 per year can he achierred if the water extraction performance is improved to reduce the moisture retention hy 25 percentape points $\left(65^{\%}\right.$ to $\left.40 \%\right)$. For a $10 \%$ discount rate and a 3 year pay hack period, a $\$ 20$ annual saving will iustify an increase in purchase cost up to $\$ 50$. However, for 5 Jear payback period the economic justifiah?e purchase price increase should not exceed $\$ 75$. 


\section{References}

I. Test Procedure for Clothes Washers, Feneral Register, Vol. 42, No. 188. Septemher 28, 1077.

2. Toner, S., "The Effects of Water Temperature on Washing Performance," Milestone Repcrt, N!ational Bureau of Stantards, Washington, D.C. T977. 


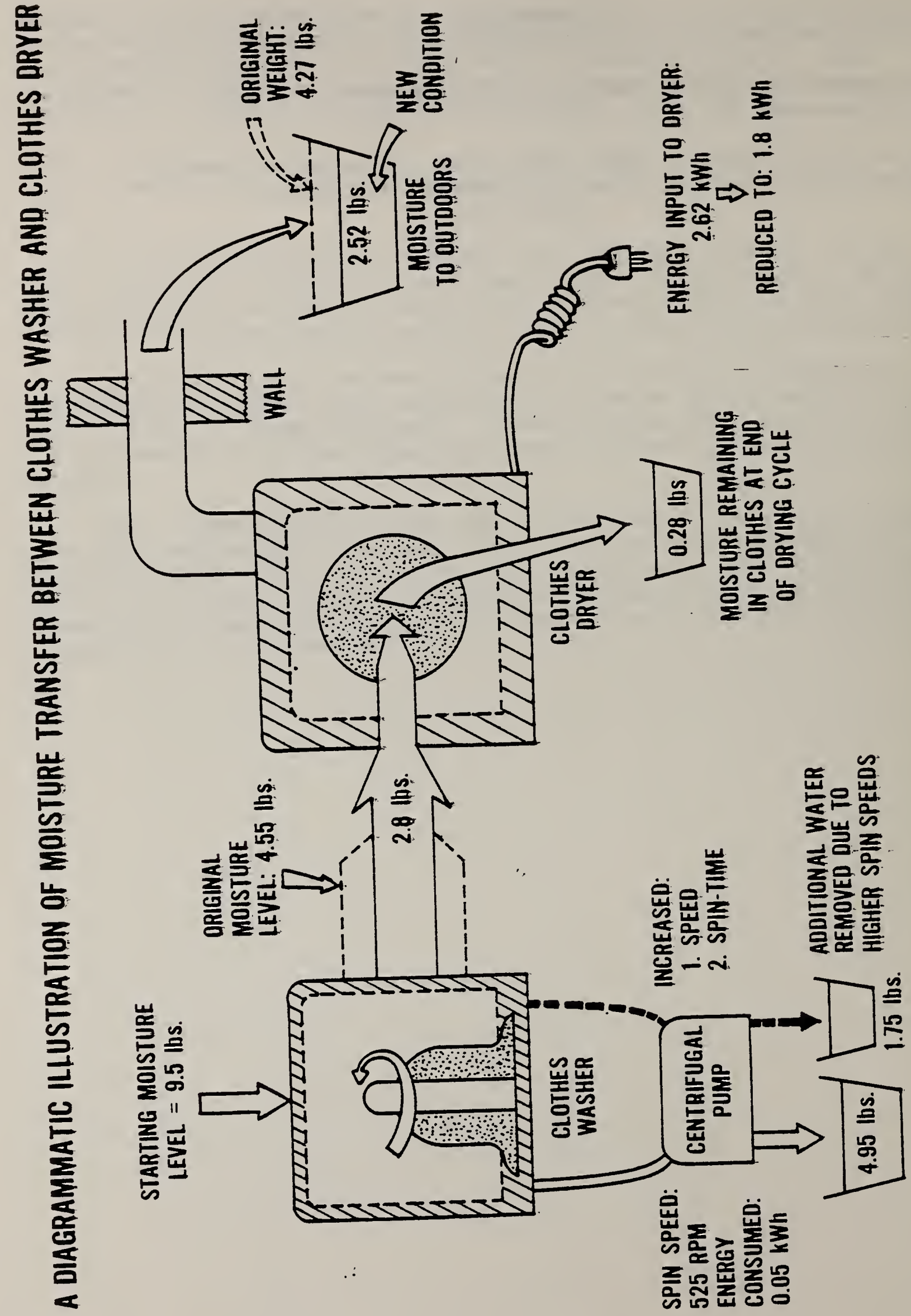




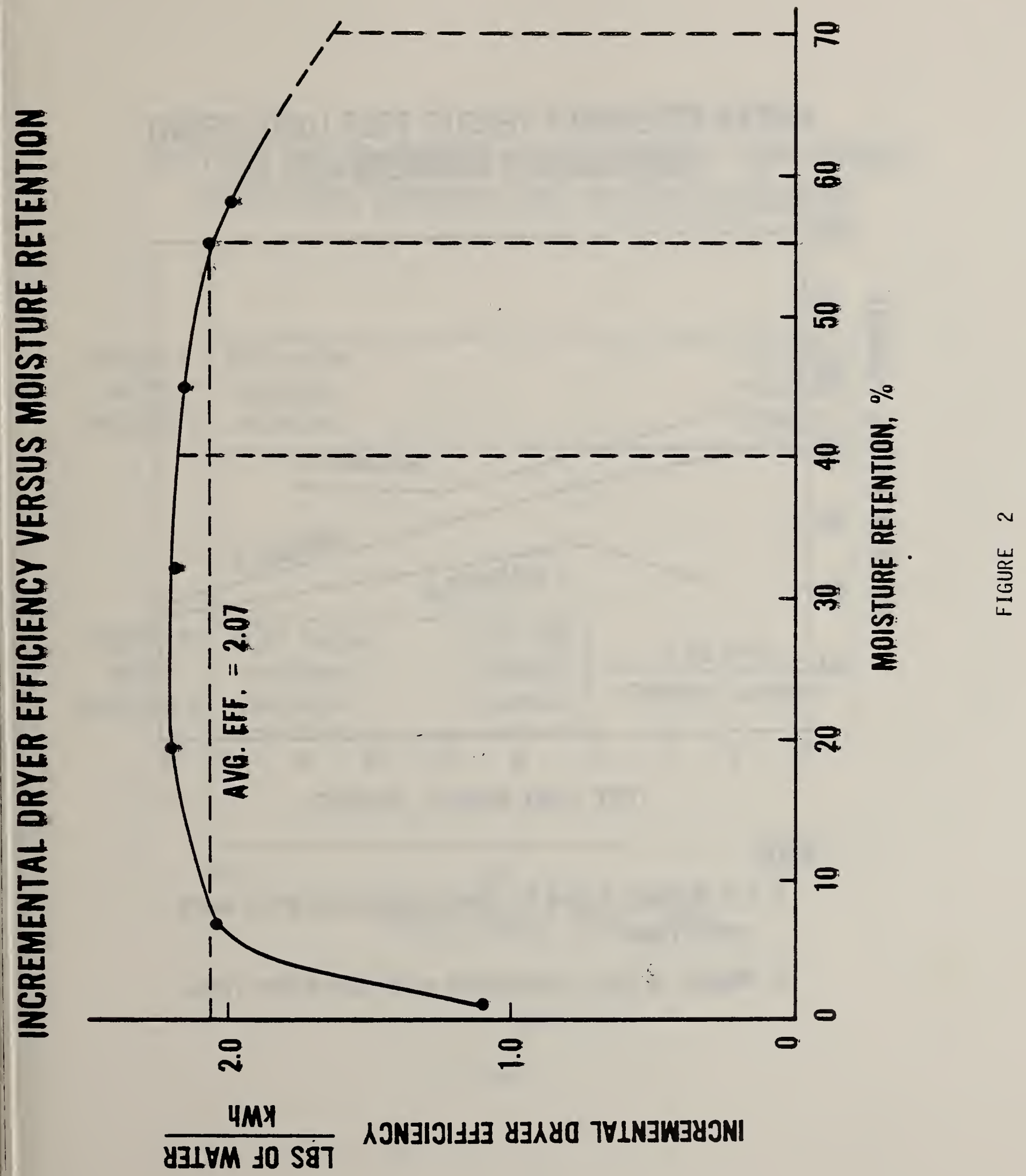




\section{WATER RETENTION VERSUS TEST LOAD WEIGHT FOR CLOTHES WASHERS A, E, H}

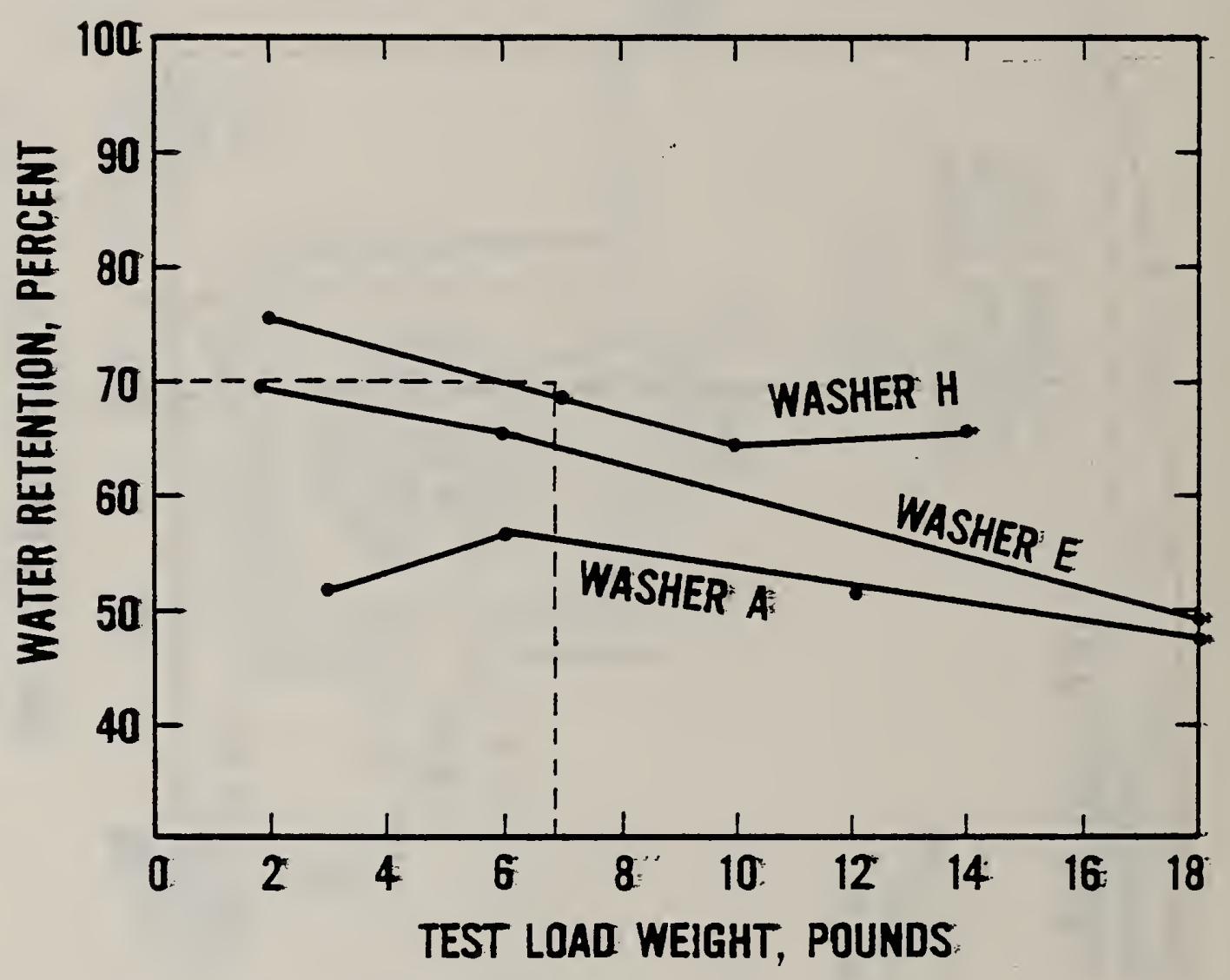

Note:

1. For Washer $A$ and $E$, test conducted with warm water rinse

2. Washer $\mathrm{H}$ test conducted with cold water rinse

FIGURE 3 


\section{CLOTHES DRYER ENERGY CONSUMPTION FOR DRYING: TEST LOADS SPUN IN TWO CLOTHES WASHERS}

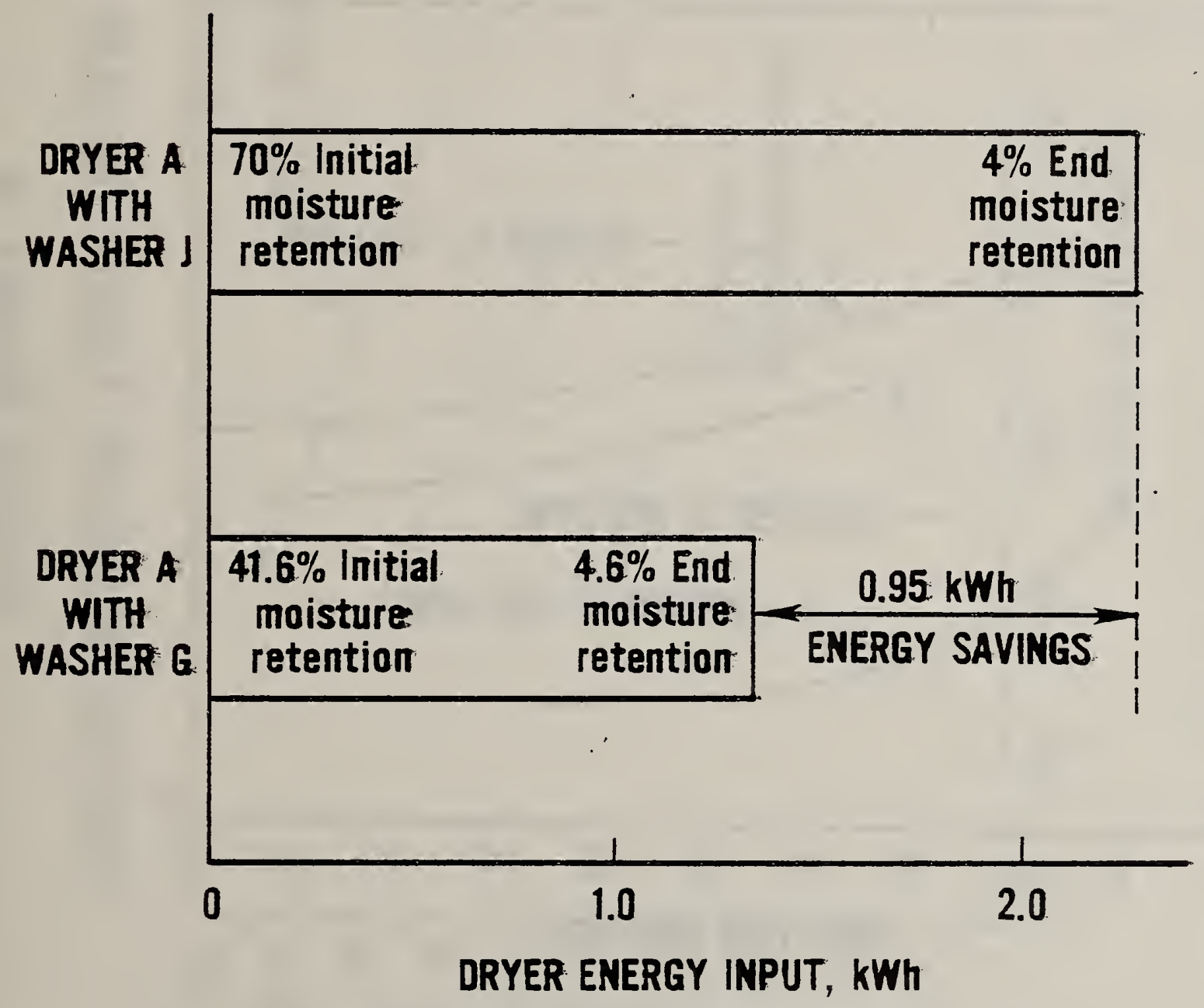

FIGURE 4 


\section{MOISTURE RETENTION VERSUS SPIN-TIME FOR THREE CLOTHES WASHERS}

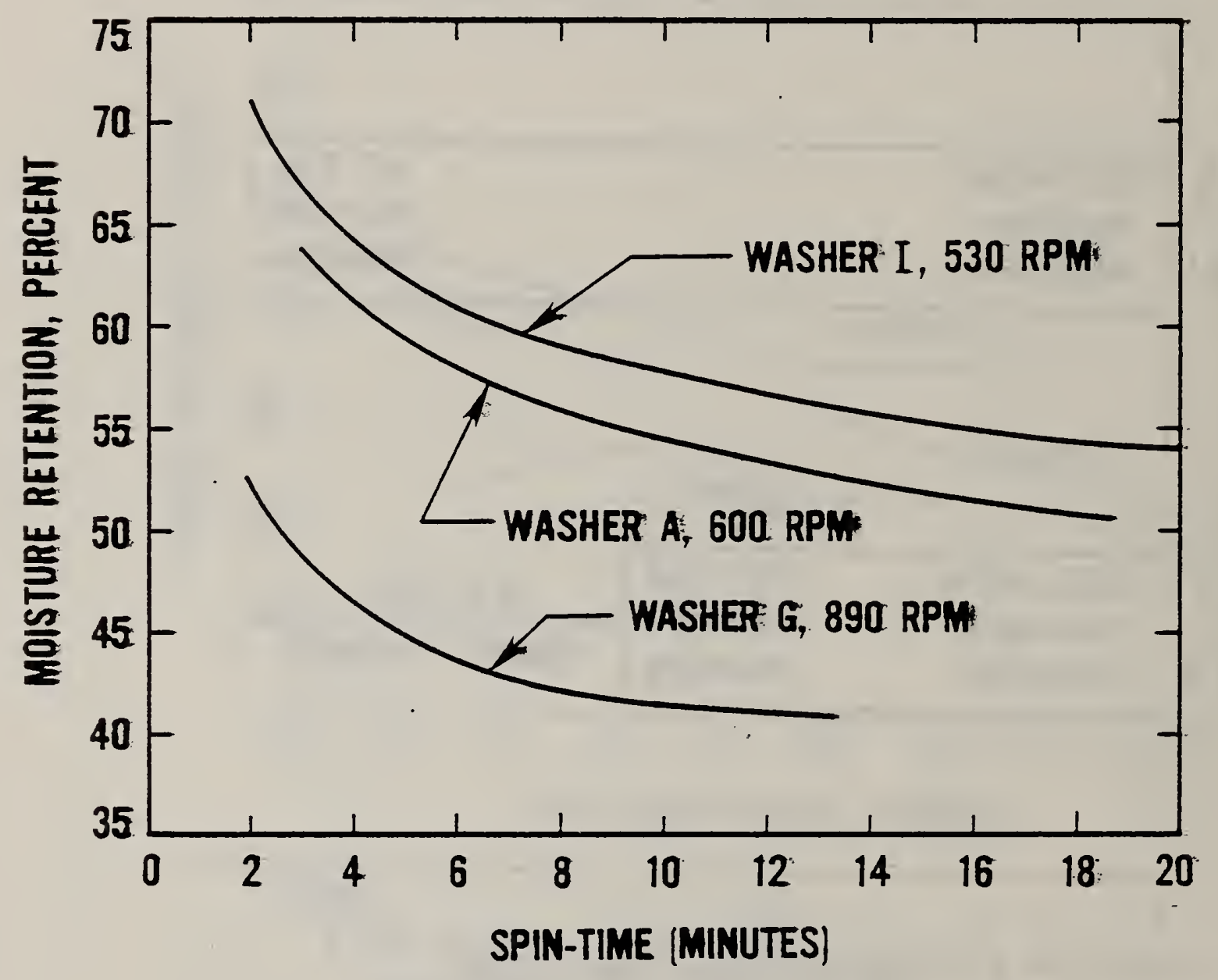

Note: Spin-cycle automatically terminates after

6 minutes for Washer I

5 minutes for washer $A$

$31 / 2$ minutes for washer $G$

FIGURE 5 


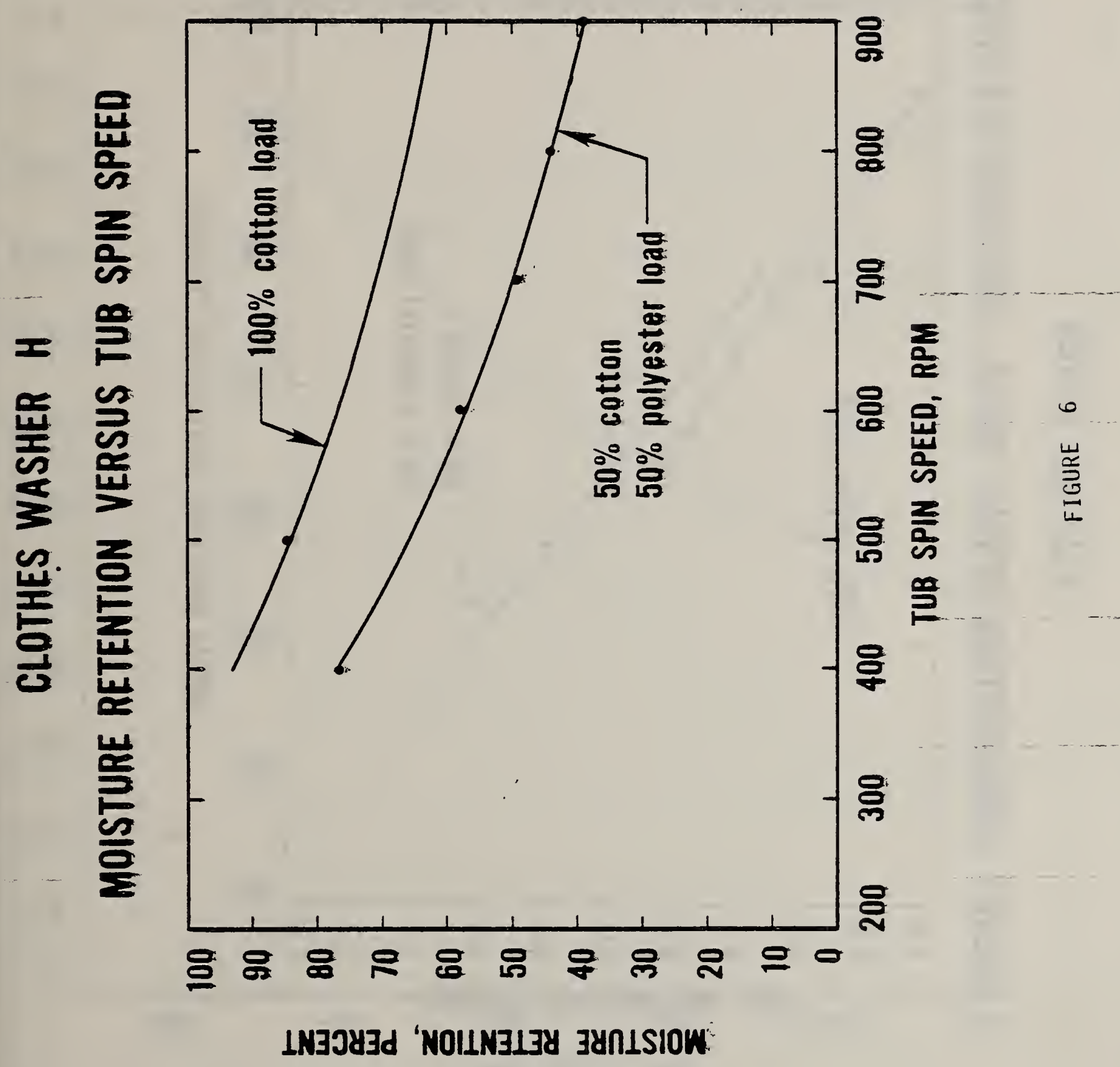




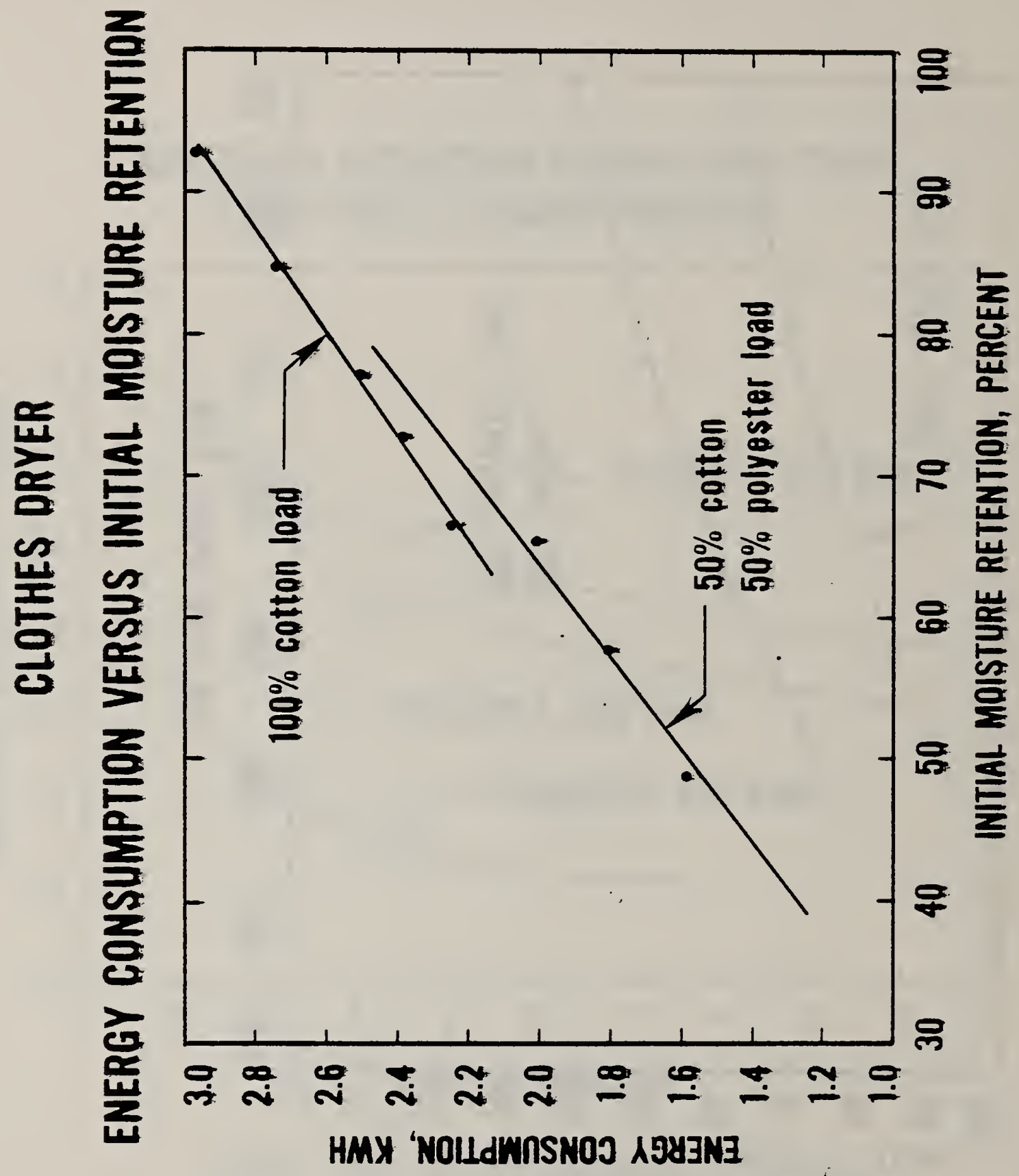




\section{CHANGE IN MOISTURE RETENTION RATE VERSUS SPIN SPEED}

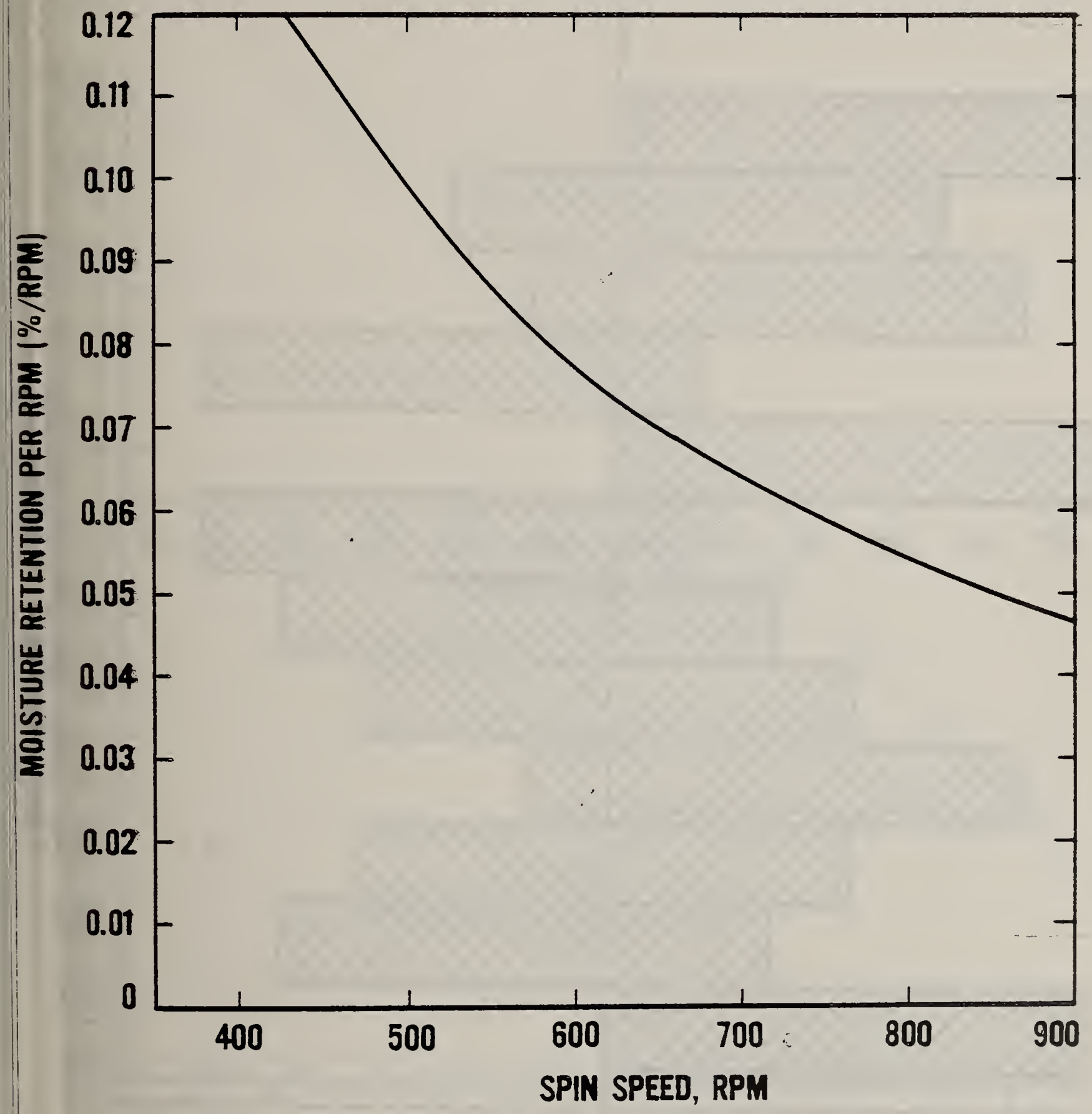

FIGURE 8 


$$
\text { \&要 } \rightarrow \mathbb{q}
$$

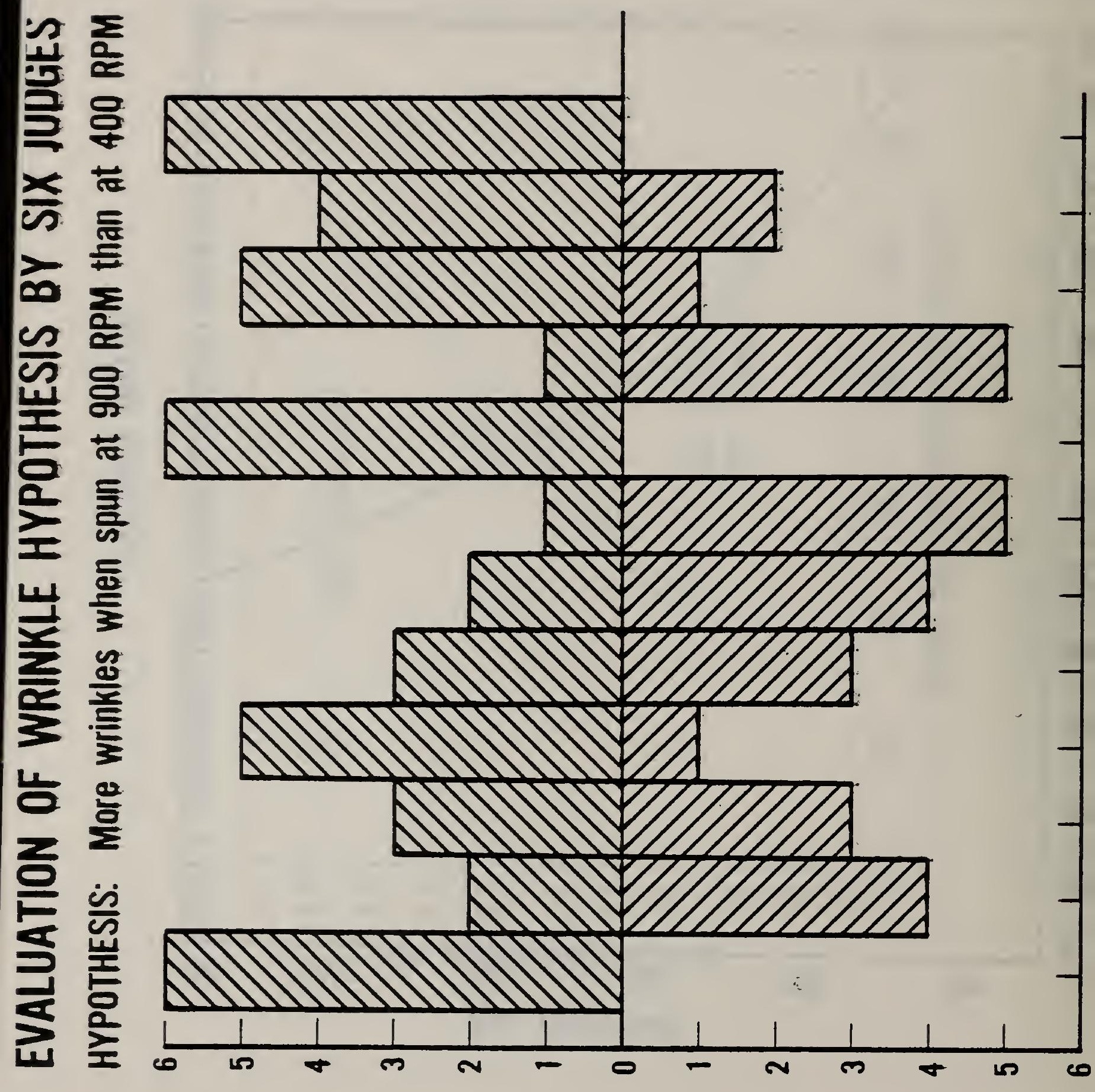

\section{WYIJNOJ SISЭHIOdגH \\ OJIVIJN SISJHLOdAH \\ AONJחOZY}




\section{CREDITS / DEBITS TO INFLUENCE THE ENERGY EFFICIENCY FACTORS OF CLOTHES WASHERS}

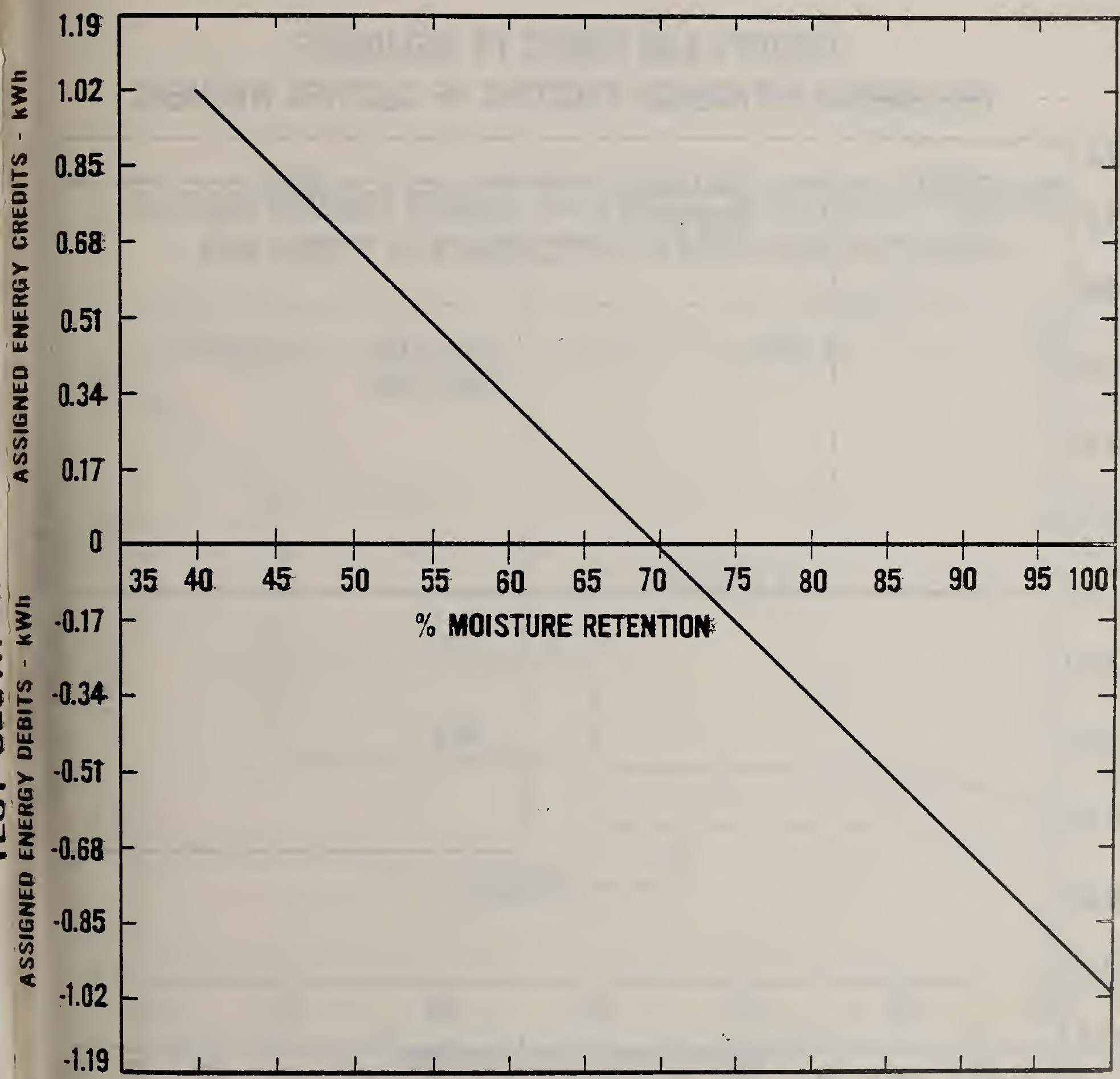


CREDITS AND DEBITS TO INFLUENCE THE ENERGY EFFICIENCY FACTORS OF CLOTHES WASHERS

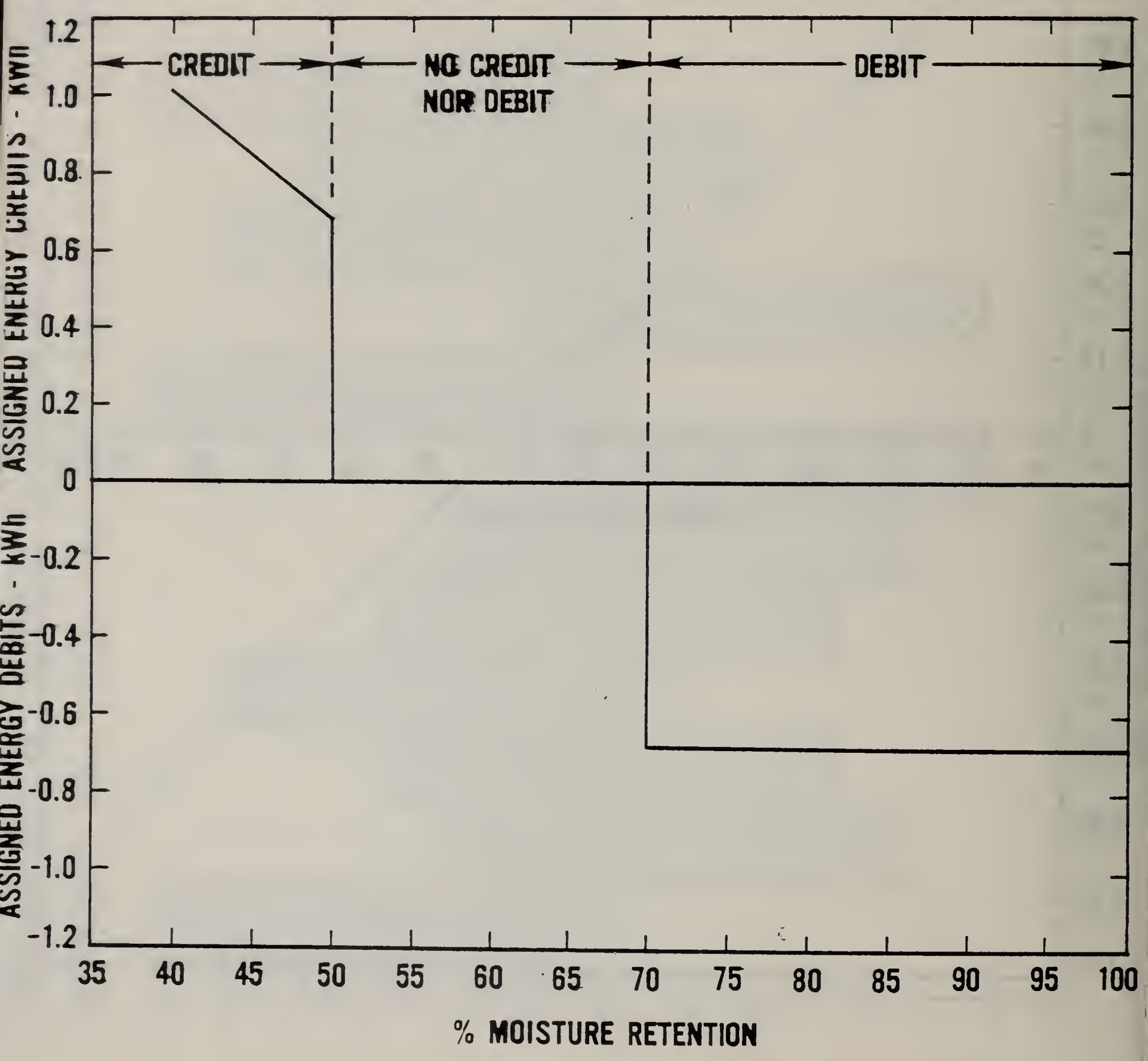




\section{CLOTHES WASHER ENERGY FACTOR, AS EFFECTED BY CREDITS AND DEBITS FOR REDUCTION IN MOISTURE RETENTION}

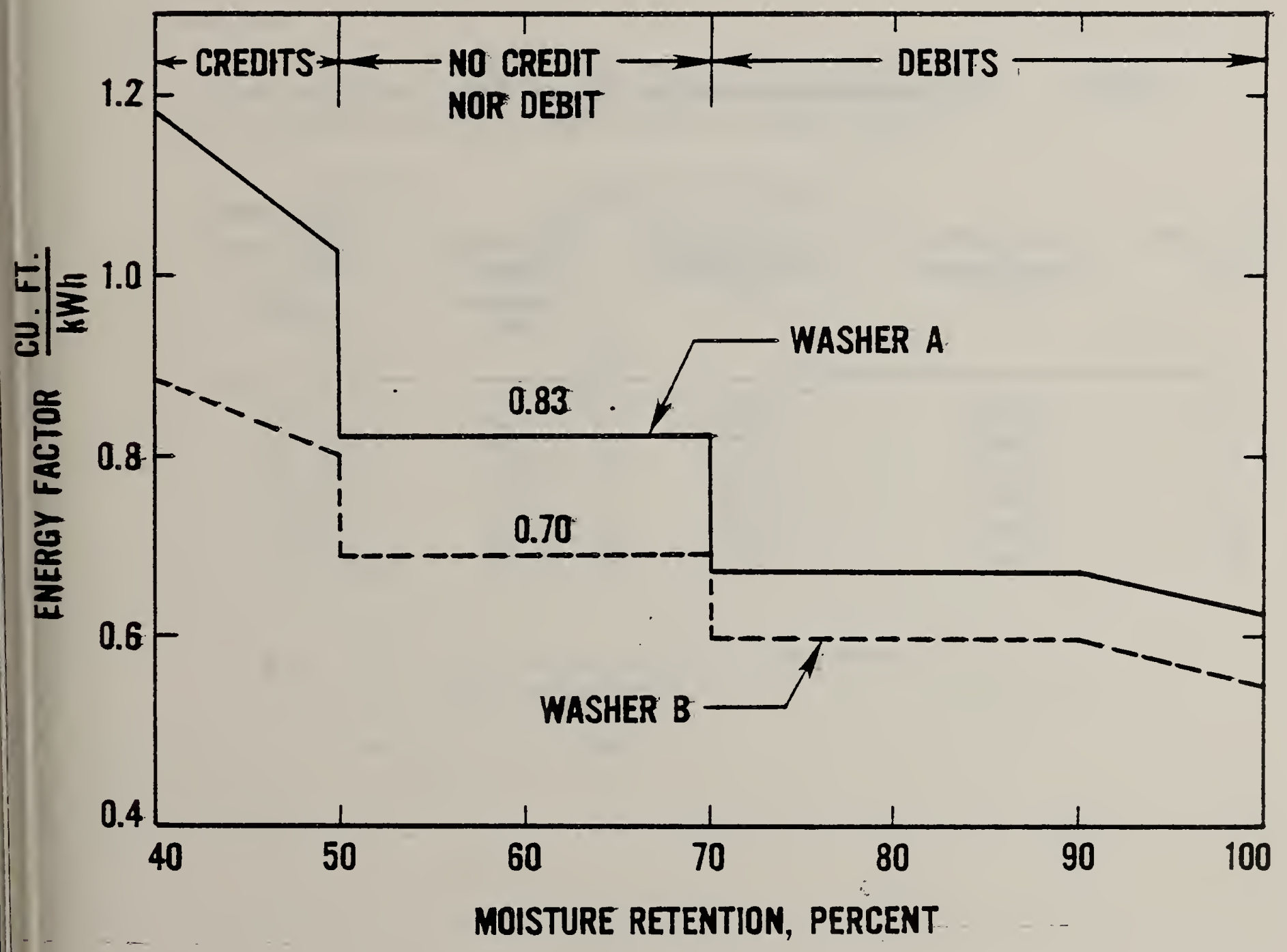


TABLI 1. Clothes Dryer Incremental Inergy Fficiency and Amunt of Nater Remover During Each 5 Mimute Interval

\begin{tabular}{|c|c|c|c|c|}
\hline $\begin{array}{l}\text { Run nime } \\
(\text { min) }\end{array}$ & $\begin{array}{l}\text { Incremental } \\
\text { Water Remover } \\
\text { (Ihs) }\end{array}$ & $\begin{array}{c}\text { Cumulative } \\
\text { Water Remover } \\
\text { (Ihs) }\end{array}$ & $\begin{array}{l}\text { Incremental } \\
\text { Enerpy } \\
\text { Consumen } \\
\text { (kih) }\end{array}$ & $\begin{array}{l}\text { Incrementa? } \\
\text { Efficiency } \\
\frac{\text { ins } \mathrm{H}_{2} \mathrm{O}}{\mathrm{Kih}}\end{array}$ \\
\hline $\begin{array}{r}5 \\
10 \\
15 \\
20 \\
25 \\
30\end{array}$ & $\begin{array}{l}0.828 \\
0.905 \\
0.927 \\
0.016 \\
0.871 \\
0.464\end{array}$ & $\begin{array}{l}0.828 \\
1.733 \\
2.660 \\
3.576 \\
4.447 \\
4.911\end{array}$ & $\begin{array}{l}0.424 \\
0.421 \\
0.424 \\
0.475 \\
0.423 \\
0.418\end{array}$ & $\begin{array}{l}1.05 \\
2.15 \\
2.18 \\
2.20 \\
2.06 \\
1.11\end{array}$ \\
\hline
\end{tabular}


TABLE 2. Water Retention for Various Clothes

Washers with 6 Pound Test Load

Machine

$$
\text { Water Retention (M) }
$$

Warm Rinse Coli Rinse

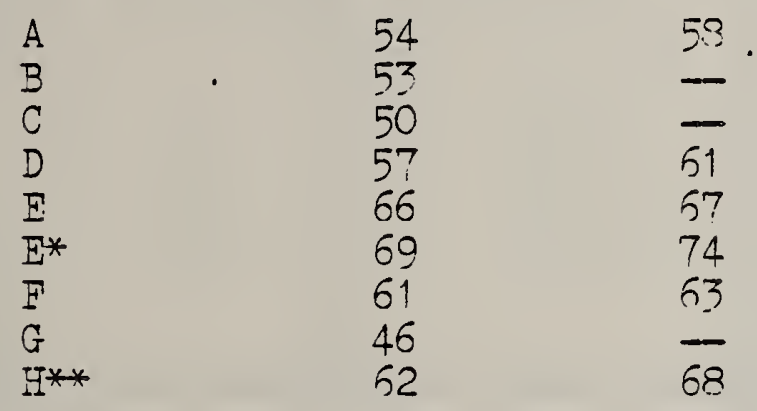

*I - 8.2 nound test loar $50 \%$ cotton, $50 \%$ po yester

*H - front Ioader 
TABLE 3. Potential. DrJer Energy Sarines for Various Moisture Retentions in a Seven Pound Test Load

\begin{tabular}{|c|c|c|c|}
\hline $\begin{array}{l}\text { Moisture } \\
\text { Retention }\end{array}$ & $\begin{array}{l}\text { Pounds of } \\
\text { Water Remaining } \\
\text { in Clothes }\end{array}$ & $\begin{array}{l}\text { Differential } \\
\text { Water Remorahle } \\
\text { Below } 70^{\circ} \text { Leve? }\end{array}$ & $\begin{array}{l}\text { Energy } \\
\text { Savine* } \\
\text { (kinh) }\end{array}$ \\
\hline $\begin{array}{l}100 \\
95 \\
90 \\
85 \\
90 \\
75 \\
70 * \\
65 \\
60 \\
55 \\
50 \\
45 \\
40\end{array}$ & $\begin{array}{l}7.00 \\
6.65 \\
6.30 \\
5.95 \\
5.60 \\
5.25 \\
4.00 \\
4.55 \\
4.20 \\
3.85 \\
3.50 \\
3.15 \\
2.80\end{array}$ & $\begin{array}{l}-2.10 \\
-1.75 \\
-1.40 \\
-1.05 \\
-0.70 \\
-0.35 \\
0 \\
0.35 \\
0.70 \\
1.05 \\
1.40 \\
1.75 \\
2.10\end{array}$ & $\begin{array}{l}-1.01 \\
-0.85 \\
-0.58 \\
-0.50 \\
-0.34 \\
-0.17 \\
0 \\
0.17 \\
0.34 \\
0.50 \\
0.68 \\
0.05 \\
1.01\end{array}$ \\
\hline
\end{tabular}

*All differential moisture remova? and enerpy savings are measurer relative to the 70 , moisture retention 7 evel and $2.07 \mathrm{lb} / \mathrm{k} \mathrm{kh}$. 
TABLE 4. Potential Dollar Energy Sarings for Various Holding Periods

\begin{tabular}{|c|c|c|c|c|}
\hline $\begin{array}{l}\text { Periods } \\
\text { Years }\end{array}$ & $\begin{array}{l}\text { Annual } \\
\text { Sarrines }\end{array}$ & $\begin{array}{l}\text { Uniform Series } \\
\text { Present North } \\
\text { Factors } \\
\end{array}$ & $\begin{array}{l}\text { Present } V a \\
\text { of Anmual Enerzy } \\
\text { Case? }\end{array}$ & $\begin{array}{l}\text { Tue } \\
\text { Sarings } 10 \\
\text { Case } 2 \\
\end{array}$ \\
\hline $\begin{array}{r}3 \\
5 \\
10 \\
15\end{array}$ & $\begin{array}{l}20 \\
20 \\
20 \\
20\end{array}$ & $\begin{array}{l}2.48 \\
3.70 \\
6.14 \\
7.60\end{array}$ & $\begin{array}{r}49.60 \\
75.80 \\
122.80 \\
152.00\end{array}$ & $\begin{array}{l}28.76 \\
43.06 \\
77.22 \\
8.16\end{array}$ \\
\hline
\end{tabular}

Note: For case 2 the present worth energy savines is arout $58 \%$ the present worth of the anmul ener py saving. 
ZABIE 5. Macinine Capacity and Eneroy Consumption Data

Washer A Washer B
1. Useful Capacity, $K_{\text {,.. }}, \mathrm{ft}^{3}$
2.71
$3: 12$
2. Energy Consumption, $E_{T}$, Winh
$3.27 \quad 4.48$

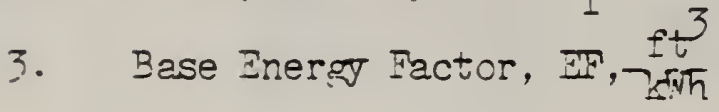
0.83
0.70 
MABLE 6. Debit/Credit from Fioure 11

\begin{tabular}{llc}
$\begin{array}{c}\text { Water } \\
\begin{array}{c}\text { Retention, R } \\
(\text {, })\end{array}\end{array}$ & $\begin{array}{c}\text { Crenit, C } \\
\text { KWh }\end{array}$ & $\begin{array}{c}\text { Dehit, C } \\
\text { kinh }\end{array}$ \\
\hline 90 & 0 & -0.68 \\
71 & 0 & 0.68 \\
$50-70$ & 0 & 0 \\
49.9 & 0.68 & 0 \\
40 & 1.01 & 0
\end{tabular}


TAELE 7. Eneroy Factor and Energy Factor Change as a Function of Water Retention for Two Washers, Using Proposed Credit/Dehit. Plan. (See Fisure 11.)

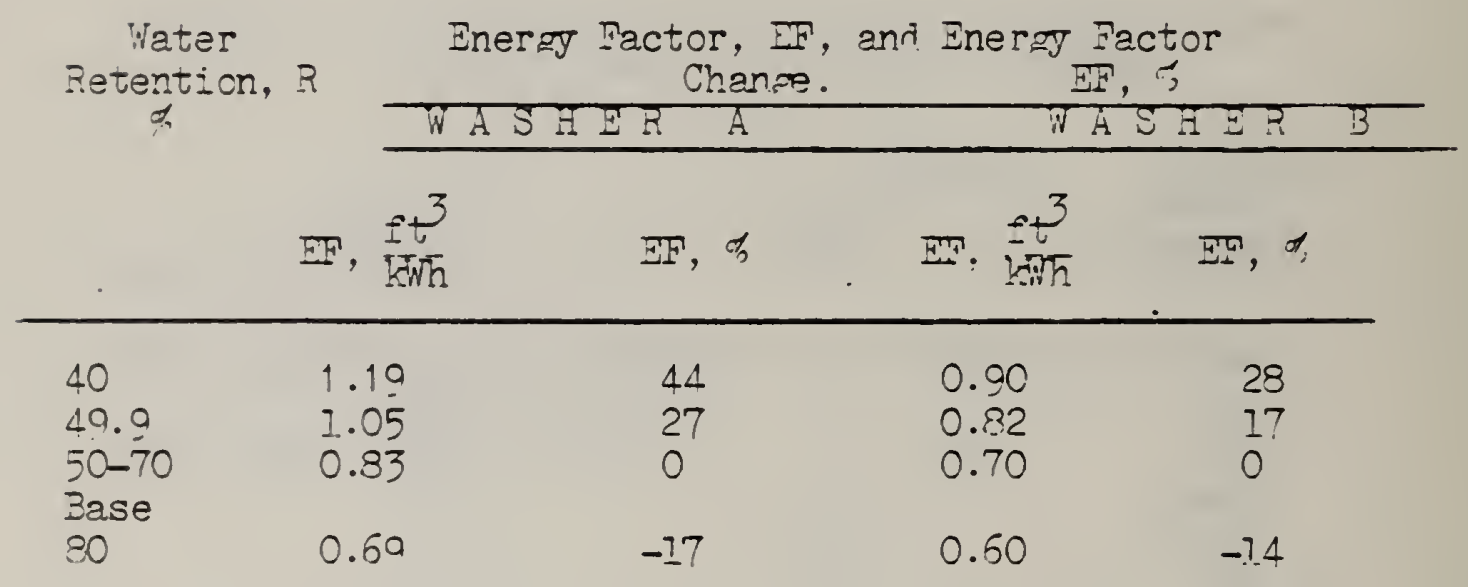


Test Procenures for Clothes Washers. Fereral Register, Vol. 42, No. 188, Wednesday, September 28, 1077.

Chapter II, Feriera] Eneroy Administration Part 430-Energy Conservation Propram for Appliances. 
Modify section 2.8.1 to rear as follows.

2.8. I Top-loader clothes washers. The top loader clothes washer sha?? he tested with a clothes load as rescriber in 2.7.1.

3.2.1.2 Moisture retention. Remove and wein the wet clothes loan at the completion of the normal cycle. Determine percent of moisture retention as foliows:

R. Disture retention, $=\frac{w_{w}-w_{h}}{w_{h}} \times 100, \alpha$

$W_{W}=$ weight of wet load upon completion of spin cycle

as ietermined accoriting to 2.5:1.7, Ihs.

$\begin{aligned} & W_{h}= \text { bone } \lambda \text { ry weight of the test Inad as deteminer accoriing to 2.7.1., } \\ & \text { Ihs. }\end{aligned}$

4.7 Ad-usted total per cycle eneroy consumption when electrically heater water is used. Calculate the adiuster tntal per cycle ener or consumption $\Xi_{A m E}$ using $\Xi_{\text {mat }}$ for electrically heater water, 3 s defined in 4.6 , expresse in kilowat hours per cycle.

$$
E_{A T E}=I_{T E}-C
$$

where:

$$
\begin{aligned}
& C=0.68+\left(\frac{50-R}{30}\right) \text { for } R<50 \\
& C=0 \text { for } 50<R \leq 70 \\
& C=-0.68 \text { for } R>70
\end{aligned}
$$

Cnange section 430.22, column 3, first pararraph (2) to rear as follows:

(2) The energy factor for automatic and semi-automatic clothes washers shall he the alutient of the cuhic foot capacity of the clothes container as determined in 3.7. of Appenxix $J$ to this sumpart divided hy the clothes washers adiuster total enerpy consumption per cycle, as ietermined in 4.7 and the result heine rounied off to the nearest 0.07 . clicic font per rilcwatt-hour. 
4. TITLE AND SUBTITLE

An Evaluation of Assigning Credit/Debit to the Energy Factor of Clothes Washers Based on Water Extraction Performance

5. $A U T H O R(S)$

\section{Denver Lovett}

6. PERFORMING ORGANIZATION (If joint or other than NBS, see instructions)

7. Conerace/Grant No.

NATIONAL BUREAU OF STANDARDS

DEPARTMENT OF COMMERCE

WASHINGTON; D.C. 20234

8. Type of Report \& Period Covered

9. SPONSORING ORGANIZATION NAME AND COMPLETE ADDRESS (Street, City, State, ZIP)

Department of Energy

1000 Independence Ave.

Washington, D. C. 20585

10. SUPPLEMENTARY NOTES

$\square$ Document describes a computer program; SF-185, FIPS Software Summary, is attached.

11. ABSTRACT (A 200-word or less factual summary of most significant information. If document includes a significant bibliography or literoture survey, mention it here)

To reduce the moisture retention of a clothes load from $65 \%$ to $40 \%$, a clothes dryer uses about 200 times more energy than a clothes washer. Therefore, improving the clothes washer's water extraction performance can significantly reduce energy-use of a dryer. For example, a clothes dryer uses about $40 \%$ less energy, when the clothes washer extracts $38 \%$ more water from the clothes load. Based on clothes washer extraction performance, NBS has developed, for the Department of Energy (DOE), a procedure for assigning credit/debit to the energy factor of a clothes washer. The purpose of this procedure is to provide an incentative for clothes washer manufacturers to improve the water extraction performance of washers. Using this procedure, the energy factors for two clothes washers improves by $44 \%$ and $28 \%$ respectively. This energy factor improvement corresponds to improved water extraction which reduces the moisture retention of the clothes 10 ad from $65 \%$ to $40 \%$. One case study shows that dryer energy savings, resulting from reduced moisture content, justifies $\$ 50$ incremental cost for improved water extraction performance for clothes washers.

12. KEY WORDS (Six to twelve entries: alphabetical order: capitalize only proper names; and separace key words by semicolons) Clothes washers; clothes dryer; extraction performance; energy savings; credits/debits; wrinkle performance

13. AVAILABILITY

Unlimited

X. For Official Distribution. Do Ńot Release to NTIS

$\square$ Order From Suderintendent of Documents, U.S. Government Printing Office, Washington, D.C. 20402.
14. NO. OF PRINTED PAGES

15. Price 


$$
\text { - }
$$

